\title{
Etymology of English Proverbs
}

\author{
Eugene E. Ivanov and Julia A. Petrushevskaia* \\ Mogilev State A. Kuleshov University \\ 1 Kosmonavtov Str., Mogilev, 212022, Belarus
}

Received 03.11.2014, received in revised form 21.12.2014, accepted 14.02.2015

The article deals with the languages of origin and sources of English proverbs. The aim of this study is to identify and quantify the rankings (based on the proportion of paremiological units) of languages of origin, personal, functional and stylistic and genre affiliation with textual sources of English proverbs. The study determines two main factors that affect the formation of the paremiological fund of the English language: the broad international and intercultural contacts (every third English proverb has foreign origin) and the writing tradition (almost half of the English proverbs goes back to written sources, different in terms of productivity and very diverse in functional and stylistic and genre affiliation). More over It finds out that English paremiological fund hasn't been subjected to significant influence of foreign languages in the new period (four out of five borrowed proverbs belong to classical languages and French, the influence of which was the most prominent on the English language in the ancient period and fully completed by the end of the middle period). The study also defines that the paremiological fund of the modern English possess a high proportion of the nationalcultural component (three out of the four authors of the English proverbs written sources turn out to be British or American).

Keywords: the English language, etymology, English paremiological fund, native English proverbs, borrowed proverbs in the English language, literary proverbs.

Research area: philology.

\section{Introduction}

Origin and sources of English proverbs are very diverse and are determined by the peculiarities of the historical dynamics of the English language, national specificity of British culture and the results of its contacts with other cultures in the world.

According to its origin, English proverbs (as in any other European language) are traditionally divided into native and borrowed (mainly from Latin and French). The main sources of origin of English proverbs are well known: folklore, the
Holy Scripture, literature (especially the works by William Shakespeare) (Zimovets, Matveeva, 2013: 27-29). However, a number of important questions remain unclear: the languages the proverbs were borrowed from, the texts that served as the sources of the proverbs, the functional, stylistic and genre variety of literary sources of proverbs, the authors who introduced many proverbs into English, etc. The problem of distinguishing the etymological and functional approaches to determinine the origin and source of proverbs wasn't solved. This fact creates very

(C) Siberian Federal University. All rights reserved

* Corresponding author E-mail address: ivanov-msu@mail.ru 
serious difficulties in description of English paremiological units, as well as their comparison with the proverbs of other languages, especially in the aspect of the opposition «national vs. universal», which is one of the most significant problems of today's paremiology.

The aim of this study is to identify and quantify the rankings (based on the proportion of paremiological units) of languages of origin, personal, functional and stylistic and genre affiliation with textual sources of English proverbs. The actual data for study were 800 proverbs that are most commonly used in the modern English language, according to the explanatory dictionary «English Proverbs Explained» (1969) R. Rideout and C. Witting (Rideout, Witting, 1969).

\section{Methodological bases}

\section{of origin and sources of proverbs}

In determining the origin and textual sources of proverbs we strictly follow the etymological approach, taking into account that many modern native English speakers may not know who it belongs to or to what literary text the proverb originated from. However, basing on the knowledge of native speakers (functional approach) only, it is very difficult characterize accurately the source of origin of the proverb.

First, this knowledge differs significantly among different speakers, and second, to identify this knowledge it is required to hold the mass experiment, aimed to precise determination of the presence / absence in linguistic consciousness of the individual of the local association with the source of each proverb (author, text and so on), which is practically impossible.

The exact origin of proverbs can't be always determined by special etymological analysis because of their predominantly verbal existence in speech, ancient origin of single proverbs and a number of productive proverb models and extralinguistic factors of paremiological borrowings. In this regard, the empirical material for the etymology of proverbs are mainly its written fixation, as well as the results of comparison of paremiological units of different languages and / or dialects.

It should be noted that the written fixation of a proverb cannot be the only sufficient basis to determine its origin and history. So, the proverb Call a spade a spade functions widely in modern English from the beginning of the twentieth century, according to R. Rideout and C. Witting, who refer to its use in the novel «The Card» (1911) by Arnold Bennett (Rideout, Witting, 1969: 67). It is possible to conclude that it has a relatively recent origin, especially as it occurs in the same form and the same meaning in the famous novel «The picture of Dorian Grey» (1890) by Oscar Wilde. However, this proverb was also used in the commentary to the Bible «Mellificium theologicum, or the marrow of many good authors» (1647) by John Trapp (cf .: Gods people shall not spare to call a spade a spade, a niggard a niggard), so that this fact significantly increases the history of the proverb, but it also may indicate its literary origin, since it has not been previously recorded. Nevertheless, we can not say that Trapp was the first to use this proverb, that he didn't borrow it from an unknown text of another author, or borrowed it directly from the oral speech. For example, we find a similar saying in the play «The Poetaster» (1601) by Ben Johnson: Ramp up my genius, be not retrograde; But boldly nominate a spade a spade (act 5, sc. 1).

There is also a version according to which the origin of this proverb originates from classical Greek (“Apophthegmata Laconica” by Plutarch, 178B). It was a mistaken translation of Ancient Greek phrase $\tau \square \sigma \square \kappa \alpha \sigma \square \kappa \alpha, \tau \square v$ $\sigma \kappa \dot{\alpha} \varphi \eta v \delta \square \sigma \kappa \alpha \dot{\alpha} \varphi \eta v \square v o \mu \alpha \dot{\sigma} \omega v$ ('calling figs figs, and a trough a trough') by the medieval scholar Desiderius Erasmus. He mistranslated the word $\sigma \kappa \alpha \dot{\varphi} \eta$ (skáphe - in English trough) as $\sigma \kappa \alpha \varphi \varepsilon i o v$ 
(skapheion - in English digging tool). The phrase was introduced to English in 1542 in Nicolas Udall's translation of Erasmus "Apophthegmes, that is to saie, prompte saiynges. First gathered by Erasmus": Philippus aunswered, that the Macedonians wer feloes of no fyne witte in their termes but altogether grosse, clubbyshe, and rusticall, as they whiche had not the witte to calle a spade by any other name then a spade. It is evident that the word spade refers to the instrument used to move earth, a very common tool. The same word was used in England, Denmark, and in the Netherlands, Erasmus' country of origin.

If we look for it in the paremiological funds of other languages, it turns out that the model of "Call / call whom / what by their right names" (and converse model with the same semantics «Do not call / Do not call whom / what by their right names) is productive in proverbs of various European languages, including the Russian language, cf .: Fr. Appeler un chat un chat; Gr. Die Dinge beim rechten Namen nennen; Sp. Llamar al pan, pan y al vino, vino; Рус. Называть вещи своими именами, Зови / Называй белое белым / черное чернымм and so on. This paremiological model is not only international, but also has a very ancient origin (it was widely used in ancient China, ancient Greece in philosophical debates about the relationship of names and things). Thus, cross-language comparison proves folk, not literary origin of the proverb Call a spade a spade.

When we were analysing contemporary English proverbs from the etymological point of view, we primarily relied on wide comparison of paremiological funds of European and a number of non-European languages (Permiakov, 1988: pp. 143-169; Gluski, 1971; Mieder, 1986; Strauss, 1994; Paczolay, 1997; Ley, 1998; Kotova, 2000; Ivanow, 2009) and we also used all available data on written fixation of proverbs (Browning, 1989;
Knowles, 2009; Simpson, 1998). We chose the most ancient sources of proverbs (their written fixation) as an empirical basis for the identification and quantitative classification of their origin. In many cases, the history and etymology of modern English proverbs supplemented with new data.

\section{The languages of origin of English proverbs}

The etymological analysis of the most common paremiological units of modern English established that there are $61.5 \%$ native English proverbs of among them (including $2.5 \%$ in American English) and $38.5 \%$ borrowed from other languages.

Borrowed proverbs can be differentiated into three groups - from classical European languages (26\%), from modern European languages (11.5\%), from non-European languages $(0.5 \%)$. Of the two classical languages, the Latin language quantitatively dominated (20\% of the units), as it was the intermediate language of the majority of borrowings from the Greek language (6\%). Modern European languages as the origins of English proverbs can be divided into two nonequilibrium groups - Languages of the United Kingdom (2\%) and the languages of continental Europe ( $9.5 \%$ units). The first group of languages includes Scottish (1.5\%) and Irish (0.5\%), the second - French (7 \%), German (0.5\%), Spanish $(0.5 \%)$ and Italian (1, $5 \%)$. Chinese and Persian ( $0.25 \%$ and $0.25 \%$ of the units respectively) belong to the group of non-European languages. The origin of a number of borrowed proverbs $(0.5 \%)$ could not be properly determined (see Table 1).

\section{The sources of English proverbs}

Native English proverbs originate more from the folklore $(43 \%)$ than to the written sources (18.5\%), and form a national-cultural component in paremiological fund of modern English. It 
Table 1. The ranked list of the languages of origin of English proverbs

\begin{tabular}{|c|c|}
\hline The languages of origin of English proverbs & The percentage of proverbs \\
\hline British English & 59 \\
\hline Latin & 20 \\
\hline French & 7 \\
\hline Ancient Greek & 2,5 \\
\hline American English & 1,5 \\
\hline Italian & 1,5 \\
\hline Scottish & 0,5 \\
\hline Irish & 0,5 \\
\hline Spanish & 0,5 \\
\hline German & 0,5 \\
\hline Chinese & 0,25 \\
\hline Persian & 0,25 \\
\hline
\end{tabular}

should be noted that the proportion of proverbs from the British and American English differs significantly depending on the source of origin. So, if the British proverbs almost 3 times more likely originate from the folklore, American proverbs are almost 20 times more likely originate from the literary sources.

English proverbs borrowed from other languages, mostly originate from a variety of written sources ( $22.5 \%)$, to a lesser extent - to the foreign language folklore $(16 \%)$. The quantity of borrowed proverbs depends on the source of origin in different languages. Thus, the borrowings from Latin twice as much originate from the literary sources as from the folklore, and from Greek -4 times (taking into account certain conventionality in the delimitation of literary and non-literary sayings in classical languages). The same situation occurs with the borrowed proverbs from Irish and German (2 times), and paremiological borrowings from Spanish and Persian originate from the written sources only. Just the opposite correlation is typical for proverbs, borrowed from Italian (5 times fewer units originate from written sources than to folklore), as well as from the Scottish (3 times less) and French (about 1.5 times fewer) languages, while paremiological borrowings from Chinese came from folklore only (see Table 2).

\subsection{Functional, stylistic}

\section{and genre variety of written sources}

of proverbs

Written sources of native English and borrowed proverbs have deep and unbalanced differentiation according to their functional, stylistic and genre affiliation. These are religious texts - the Holy Scriptures (6.5\%), theological works $(1.5 \%)$, sermons $(0.5 \%)$, laws and statutes of religious communities (0.5\%); legal texts $(0.5 \%)$; scientific texts - treatises on philosophy (4.25\%), philology (0.5\%), history (0.75\%), social and political issues (less than $0.15 \%$ ), medicine (less than $0.15 \%$ ), geography (less than $0.15 \%$ ), agriculture (less than $0.15 \%$ ); texts of mass communication - mottos and slogans $(0.5 \%)$; publicistic texts - articles in newspapers and magazines ( $1 \%)$, pamphlets $(0.5 \%)$, almanacs (less than $0.15 \%$ ); public speeches (1.5\%); genealogical records $(0.25 \%)$, memoirs $(0.25 \%)$, 
Table 2. The ranked list of languages of origin of English proverbs in relation to their sources

\begin{tabular}{|l|c|c|}
\hline \multicolumn{1}{|c|}{ The languages of origin of English proverbs } & $\begin{array}{c}\text { The percentage of folk } \\
\text { proverbs }\end{array}$ & $\begin{array}{c}\text { The percentage of } \\
\text { literary proverbs }\end{array}$ \\
\hline British English & 43 & 16 \\
\hline Latin & 7 & 13 \\
\hline French & 4,25 & 2,75 \\
\hline Italian & 1,25 & 0,25 \\
\hline Ancient Greek & 1,15 & 4,85 \\
\hline Scottish & 1,15 & 0,35 \\
\hline The Language of origin is not defined & 0,5 & - \\
\hline Chinese & 0,25 & 2,35 \\
\hline American English & 0,15 & 0,35 \\
\hline Irish & 0,15 & 0,35 \\
\hline German & 0,15 & 0,5 \\
\hline Spanish & - & 0,25 \\
\hline Persian & - & \\
\hline
\end{tabular}

epistolary texts $(1 \%)$; literature - poetry $(9 \%)$, prose $(6 \%)$, dramatic works $(5.25 \%)$ in various genres (see Table 3).

\subsection{Authorship of English proverbs with literary origin}

The vast majority of proverbs of written sources have the author, but there are no more than $1 \%$ of the English proverbs from anonymous written sources. The most important of these texts is a set of rules (laws) of the monk's life «Ancrene Riwle (Ancrene Wisse)», which dates from 1250 and was a source of several modern English proverbs. More over the anonymous written sources include newspapers and magazines («The Thames Journal» $\mathrm{XIX}^{\text {th }}$ centuries, "The New York Gazette \& Weekly Mercury" XVIII ${ }^{\text {th }}$ centuries), genealogical records ("The Loseley manuscript" $\mathrm{XVI}^{\text {th }}$ centuries) and others.

The total number of the British authors of literary English proverbs (we excluded Latin and Greek authors, as the lack of reliable data makes it impossible to establish the primacy of the proverb wording) is sufficiently large, but extremely unbalanced on linguistic grounds. Thus, it was found out that the English-speaking authors prevail. Their proverbs are used 3 times more often than those of others. It should be stated that the proverbs of British-English authors are 6 times more frequent than those of the AmericanEnglish ones (The number of the British authors of literary English proverbs is $16 \%$, while the number of the American-English ones is 2, $35 \%$ ) (see table 4).

We analysed the written sources of native English proverbs using the chronological, stylistic and functional approaches. This research resulted in the following data.

XIII-XVI c. are associated with low percentage of replenishment of paremiological fund from English literature. The completion was primarily realised by religious, literary, scientific texts, as well as the texts of mass communication.

The period from the XVI to XVIII c. was the most productive. The proverb stock was significantly enlarged by British writers, poets, 
Table 3. The ranked list of sources of English proverbs

\begin{tabular}{|c|c|}
\hline The sources of English proverbs & The percentage of proverbs \\
\hline Folklore & 59 \\
\hline Literature ( poetry / prose / dramatic works) & $20,25(9 / 6 / 5,25)$ \\
\hline The Holy Scripture (Old Testament / New Testament) & $6,5(2,5 / 4)$ \\
\hline Treatises on philosophy & 4,25 \\
\hline Theological works & 1,5 \\
\hline Public speeches & 1,5 \\
\hline Publicistic texts (articles in newspapers and magazines) & 1 \\
\hline Epistolary texts & 1 \\
\hline Treatises on History & 0,75 \\
\hline Mottos and slogans & 0,5 \\
\hline Laws and statutes of religious communities & 0,5 \\
\hline Pamphlets & 0,5 \\
\hline Sermons & 0,5 \\
\hline Treatises on Philology & 0,5 \\
\hline Legal texts & 0,5 \\
\hline Memoirs & 0,25 \\
\hline Genealogical records & 0,25 \\
\hline Almanacs & 0,15 \\
\hline Treatises on Geography & 0,15 \\
\hline Treatises on Medicine & 0,15 \\
\hline Treatises on Agriculture & 0,15 \\
\hline Treatises on Social and political issues & 0,15 \\
\hline
\end{tabular}

playwrights' sayings, it was slightly less influenced by the authors of scientific texts (philosophical, historical, social, political, etc.), religious texts still remain one of the sources of replenishment the English language with paremiological units. New sources that gave a number of set expressions which, finally were perceived as a proverb publicistic texts, genealogical records, memoirs, epistolary texts.

In the XVIII - XIX c. the important sources of origin and spreading of proverbs were the literary texts; the epistolary texts, memoirs, genealogical records were of smaller influence. The religious and scientific texts, as well as the texts of mass communication, public speeches as a source of proverbs, were not recorded.
During the XIX - XX c. literary texts were still one of the main sources of new English proverbs. Scientific, publicistic texts and the texts of mass communication have also influenced the contents of English proverbs in a given period.

It should be noted that such a wide differentiation of written sources of native English proverbs on the basis of their belonging to a particular author convincingly demonstrates an extremely strong impact of books and written tradition on the formation of the English paremiological fund in the middle and the new periods (without a number of significant dominance of citations of any author).

It is significant that the quotations from the works by William Shakespeare do not occupy a 
Table 4. The ranked list of languages of origin of English proverbs in relation to the authorship of their written sources

\begin{tabular}{|c|c|}
\hline Languages of origin of English proverbs & The number of authors of literary proverbs \\
\hline British English & 82 \\
\hline French & 17 \\
\hline American English & 14 \\
\hline Irish & 3 \\
\hline Spanish & 3 \\
\hline Scottish & 3 \\
\hline Italian & 2 \\
\hline German & 2 \\
\hline Persian & 1 \\
\hline Chinese & - \\
\hline The Language of origin is not defined & It was not defined \\
\hline Latin & It was not defined \\
\hline Ancient Greek & \\
\hline
\end{tabular}

significant place in the fund of English proverbs, which is usually attributed to them. Their number is only 18 units (a little more than $2 \%$ ) among the 800 most common modern English proverbs. However, if we compare this number with the proverbs by other well-known English writers, we'll see that the number of proverbs by $\mathrm{W}$. Shakespeare is 2.5 times more than the number of proverbs by his nearest competitor G. Chaucer (7 units) and 4.5 times such British authors as F. Bacon (5 units), A. Pope (4 units) and G. Lily (4).

While the analysis of the written sources of American English proverbs, we used the same criteria as during the analysis of native English proverbs, as the result we obtained the following data.

The United States was founded in the second half of the XVII century, that's why its influence on the English paremiological fund has started since the XVIII - XIX centuries. This period is characterized by the influence of the authors of literary texts (prose), texts of newspaper and magazine articles, epistolary texts, as well as the authors of legal texts and texts of oral speeches.
Between the XIX - XX centuries the significant sources of origin and spreading of proverbs were the literary texts (prose and poetry), the publicistic texts, as well as the texts of oral speeches.

\section{Conclusion}

Etymological analysis and quantitative ranking (based on the proportion of proverbs) of languages of origin of the most common proverbs in Modern English have shown that the English paremiological fund was formed under the influence of two factors. The first factor is the broad and intercultural contacts, which resulted in a very large proportion of borrowed proverbs (every third English proverb is of foreign origin). The second - the book-writing tradition, due to which nearly half of English proverbs originates from written sources, which are different in terms of productivity and diverse in their functional and stylistic and genre affiliation. However, the English paremiology always remained rather closed to outside influences in comparison with the paremiological funds of other languages. Four out of five borrowed proverbs originate from 
classical languages and French. The influence of these languages on English was the most active in the ancient period and almost completed by the end of the Middle English period. While three out of four authors of written sources of English proverbs are British or Americans. The mentioned facts give us grounds to make a conclusion about the role of the national-cultural component in the paremiological fund of modern English. The fact that there are a number of native proverbs in the modern English paremiological fund proves the self-sufficiency and relatively fast development of the English language throughout its historical development. It also proves the status of English as one of the major languages of international contacts in today's world.

\section{References}

1. Browning, D.C. Everyman Dictionary of quotations and proverbs. London: Chancellor Press, 1989. $745 \mathrm{p}$.

2. Gluski, J. Proverbs: A Comparative Book of English, French, German, Italian, Spanish and Russian Proverbs with a Latin Appendix. New York: Elsevier Publishing, 1971. 486 p.

3. Ivanow, Ja. Ja. Anglo-belaruski parjemijalagichny slownik. [English-Belarusian Paremiological Dictionary]. Magiljow: MDU imja A.A. Kuljashova, 2009. 240 p.

4. Knowles, E. The Oxford Dictionary of Quotations, 7th ed. USA: Oxford University Press, 2009. $1184 \mathrm{p}$.

5. Kotova, M. Iu. Russko-slavianskii slovar' poslovits s angliiskimi sootvetstviiami. [RussianSlavic Dictionary of Proverbs with English Correspondences]. S.-Peterburg: SPbGU, 2000. 360 p.

6. Ley, G. International Dictionary of Proverbs. New York: Hippocrene Books, 1998. 580 p.

7. Mieder, W. Encyclopedia of World Proverbs. Englewood Cliffs, N.J.: Prentice-Hall, 1986. $582 \mathrm{p}$.

8. Paczolay, G. European Proverbs in 55 Languages, with Equivalents in Arabic, Persian, Sanskrit, Chinese, and Japanese. Veszprém (Hungary): Veszprémi Nyomda, 1997. 528 p.

9. Permiakov, G. L. K voprosu o paremiologicheskom minimume iazyka (na materiale russkikh narodnykh izrechenii). In: Osnovy strukturnoi paremiologii. [Paremiological Minimum of the Language (based on Russian Folk Sayings). In: Structural Paremiology]. Moscow: Nauka, 1988. pp. $143-169$.

10. Ridout, R. and Witting, C. English Proverbs Explained. London: Pan Books LTD, 1969. $223 \mathrm{p}$.

11. Simpson, D. and Speake J. The Concise Oxford Dictionary of Proverbs, 3rd ed. USA: Oxford University Press, 1998. 333 p.

12. Strauss, E. Dictionary of European proverbs. New York: Routledge, 1994. 789 p.

13. Zimovets, N.V. and Matveeva, A.A. $K$ voprosu o proiskhozhdenii angliiskikh poslovits $i$ pogovorok. In: Aktual'nye voprosy perevodovedeniia i praktiki perevoda: sb. nauch. st. [The Origin of English Proverbs and Sayings. In: Current Issues of Translation Studies and Practice of Translation: Collected articles]. N. Novgorod: Biuro perevodov “Al'ba", 2013, No.3, pp. 27-29. 


\title{
Этимология английских пословиц
}

\author{
Е.Е. Иванов, Ю.А. Петрушевская \\ Могилевский государственный университет \\ имени А.А. Кулешова
}

Республика Беларусь, 212022, Могилев, ул. Космонавтов, 1

\begin{abstract}
Данная статья посвящена определению языков происхождения и источников возникновения английских пословиц. Цель данного исследования состоит в выявлении и количественном ранжировании (на основании удельного веса паремиологических единии) языков происхождения, персональной, функционально-стилистической и жанровой принадлежности текстовых источников английских пословиц. Определены два основных фактора, воздействовавших на формирование паремиологического фонда английского языка: широкие межъязыковые и межкультурные контакты (каждая третья английская пословица имеет иноязычное происхождение) и книжно-письменная традиция (почти половина английских пословиц восходит $к$ письменным источникам, различным по продуктивности и весьма разнообразным по своей функичонально-стилистической и жанровой принадлежности). Более того, было установлено, что паремиологический фонд английского языка не подвергался существенному иноязычному влиянию в новый период (четыре из пяти заимствованных послович приходятся на классические языки и франиузский язык, влияние которых на английский язык было наиболее активным в древний период и полностью завершилось к кониу среднего периода). В статье также установлено, что в составе паремиологического фонда современного английского языка высок удельный вес национально-культурного компонента (три из четырех авторов письменных источников английских пословиц являются британц̧ами или американц̧ами).

Ключевые слова: английский язык, этимология, английский паремиологический фонд, исконно английские пословицы, заимствованные пословицы в английском языке, пословицы литературного происхождения.
\end{abstract}

Научная спеииальность: 10.00.00 - филологические науки. 